\title{
Agnieszka Nowok-Zych
}

Akademia Muzyczna im. K. Szymanowskiego w Katowicach

\section{Mieczysław Wajnberg a kategoria pogranicza}

\section{Abstract}

\section{Mieczysław Wajnberg and the Category of Borderland}

Polish musicologist and author Danuta Gwizdalanka, titled her publication Mieczysław Wajnberg: Composer from Three Worlds (Poznań, 2013). Wajnberg (1919-1996) was a Polish composer with Jewish roots who spent most of his life in USSR. Without any doubt, Wajnberg can be named "the composer from the borderland" due to his "hybrid identity", which was one of the most important reasons preventing appreciation of Wajnberg's creative activity both during life and after death. The main ideas of the paper are focused on the "category of borderland" and its representation in Wajnberg's biography and output. According to the typology proposed by Krzysztof Zajas, Wajnberg's live and works can be considered in the frame of following types of borderland: interdisciplinary, spatial, psychological, existential, sociological and mythological. Through the prism of "borderland's category", Wajnberg's creative activity shows itself as a very individual and invaluable testimony of his times (far away from eclectic and epigonic in relation to music of Dmitri Shostakovich), unique on the scale of world music literature. 


\section{Keywords}

Mieczysław Wajnberg, borderland, identity, Krzysztof Zajas

„Mieczysław Wajnberg: kompozytor z trzech światów” - tak zatytułowała jedyną jak dotąd w polskiej literaturze muzykologicznej biografię kompozytora Danuta Gwizdalanka ${ }^{1}$. Polski twórca o żydowskich korzeniach, który ponad pięć dekad żył i tworzył w Związku Radzieckim... Już tak krótki opis nastręcza pewnych trudności w określeniu kulturowej przynależności Wajnberga. Intuicja podpowiada, iż trafnym będzie określenie „twórca z pogranicza”, jednak to właśnie „hybrydyczna tożsamość" kompozytora stanowiła główną przeszkodę w docenieniu jego artystycznej działalności tak za życia, jak i po śmierci. Bez wątpienia bliskość trzech kręgów kulturowych wywarła znaczący wpływ na podejmowane przez Wajnberga artystyczne wybory. W jaki sposób kategoria pogranicza wpisuje się zatem w biografię i twórczość kompozytora? Czy - a jeśli tak, w jaki sposób - można interpretować muzyczną spuściznę Wajnberga przez jej pryzmat? Na łamach artykułu pragnę podjąć próbę odpowiedzi na postawione pytania.

Słowo „pogranicze” odsyła nas zawsze do pojęcia granicy. Włodzimierz Próchnicki w swoim artykule Pogranicza bez granic zwraca jednak uwagę, iż granica stanowi linię, natomiast pogranicze - powierzchnię. Choć nierozerwalnie wiąże się z granicą, jest obszarem nie do końca poddającym się zdefiniowaniu, pozostającym $\mathrm{w}$ pewnym sensie otwartym ${ }^{2}$. Pogranicza zawsze są heterogeniczne; właściwe dla nich są „osobność”, i „przenikanie”, generujące pełne napięcia opozycje takie jak „swój” kontra „obcy”, nieraz o charakterze wartościującym ${ }^{4}$.

1 D. Gwizdalanka, Mieczysław Wajnberg: kompozytor z trzech światów, Teatr Wielki im. Stanisława Moniuszki w Poznaniu, Poznań 2013.

2 W. Próchnicki, Pogranicza bez granic, w: Na pograniczach literatury, red. J. Fazan, K. Zajas, Biblioteka Literatury Pogranicza, t. 21, seria pod red. A. Romanowskiego, Kraków 2012, s. 35.

3 W. Panas, O pograniczu etnicznym w badaniach literackich, w: Wiedza o kulturze i edukacja. Księga referatów Zjazdu Polonistów, red. T. Michałowska, Z. Goliński, Z. Jarosiński, Instytut Badań Literackich PAN, Warszawa 1996.

4 W. Próchnicki, Pogranicza..., dz. cyt., s. 36-37. W związku z elementem wartościującym pogranicza często stanowią temat badań postkolonialnych. Przykłady interesującej literatury na ten temat, m.in.: J. Kieniewicz, Ekspansja, kolonializm, cywilizacja, Wydawnictwo DiG, Warszawa 2008; H. Bhabha, Mimikra i ludzie. 
Jak zaznacza Próchnicki, granica nie musi istnieć w sensie geograficznym. Ujawnia się w postaci różnic w obrębie języka i kultury zarówno wśród sąsiadujących ze sobą społeczeństw, jak i tych, których dzielą znaczne geograficzne odległości ${ }^{5}$; realne granice zatem nie stanowią przeszkód dla powstania różnic. Pociąga to za sobą odmienne sposoby artystycznego myślenia, jak i istną fuzję wzajemnych wpływów - twórczość Wajnberga okazuje się tego znakomitym przykładem.

$\mathrm{W}$ humanistycznej literaturze naukowej nie brak różnorodnych propozycji typologii pogranicza. O tym, iż „pogranicze" należy do wciąż dynamicznie rozwijających się kategorii, świadczy m.in. artykuł Grzegorza Babińskiego, który postuluje np. przyjęcie podziału na pogranicza stare i nowe ${ }^{6}$. Najbardziej uniwersalna zdaje się jednak generalna typologia zaproponowana przez Krzysztofa Zajasa, który wyróżnia pogranicza: interdyscyplinarne, przestrzenne, psychologiczne

O dwuznaczności dyskursu kolonialnego, w: H. Bhabha, Miejsca Kultury, przeł. T. Dobrogoszcz, Kraków 2010; Ch. Sandoval, Methodology of the Opressed, London Minneapolis 2000.

5 Tamże, s. 37.

6 G. Babiński, Przemiany pograniczy narodowych i kulturowych - propozycje typologii, w: Polskie pogranicza a polityka zagraniczna u progu XXI wieku, red. R. Stemplowski, A. Żelazo, Warszawa 2002, s. 18. Do starych zalicza pogranicza: a) terytorialne; b) historyczne; c) o znacznym zakresie przenikania kultur, a więc i podobieństwie mieszkających tam zbiorowości; d) częściej przejściowe niż stykowe; e) przy braku ostrych podziałów i granic między zbiorowościami; f) o zróżnicowaniu ekonomicznym i społecznym, które to zróżnicowanie nie ma charakteru ostrych podziałów (widoczna ciągłość i pełność stratyfikacji społecznej); g) między „całościami społecznymi”; h) ewoluujące od akceptacji kultur podległych do równości kulturowej, ale zasadniczo raczej wertykalnymi relacjami międzykulturowymi i tożsamościowymi, i istotnej, acz nie konstytutywnej dla podziałów społecznych roli zróżnicowania religijnego. $\mathrm{Z}$ kolei w kategorii nowych Babiński proponuje: a) w niewielkim stopniu terytorialne (o nieokreślonym lub tylko symbolicznym terytorium); b) „ahistoryczne”; c) o znaczącym zróżnicowaniu kulturowym i dystansach cywilizacyjnych; d) stykowe w znaczeniu zarówno terytorialnym, jak i kulturowym; e) o granicach grupowych wyraźnych, ale często tylko symboliczno-tożsamościowych; f) o zróżnicowanym charakterze różnic społecznych i ekonomicznych (mogą być zarówno bardzo duże, jak i minimalne - brak ukształtowanej pełnej stratyfikacji społecznej); g) między wyselekcjonowanymi na skutek procesów migracyjnych zbiorowościami społecznymi; h) przy wyraźnym (zwłaszcza od strony mniejszości) horyzontalnym charakterze postrzegania relacji międzykulturowych; i) przy bardzo istotnym znaczeniu zróżnicowania religijnego. 
i egzystencjalne, socjologiczne oraz mitologiczne ${ }^{7}$. Pogranicze interdyscyplinarne rozumie jako przenikanie dyskursów naukowych, wykorzystanie narzędzi badawczych różnorodnych dyscyplin ${ }^{8}$. Podejmując się badania twórczości kompozytora takiego jak Mieczysław Wajnberg, badacz musi zdawać sobie sprawę z konieczności uzupełnienia swojej wiedzy o obszary tematyczne z zakresu historii, socjologii, religioznawstwa, literatury czy antropologii - dziedzin niezbędnych dla stworzenia jak najpełniejszej interpretacji jego artystycznego dorobku.

Pogranicze przestrzenne dotyczy konkretnej przestrzeni terytorialnej, w tym małych ojczyzn, stwarzających warunki dla wspólnej egzystencji wielu kultur i warunkujących powstanie specyficznych w swej formie lub języku dzieł. W przypadku Wajnberga pogranicze przestrzenne i jego wpływ na twórczość kompozytora wydają się jedną $\mathrm{z}$ najbardziej istotnych reprezentacji tego terminu w interpretacji Zajasa. Wajnberg wywodził się z rodziny mołdawskich Żydów, którym udało się uciec przed pogromem w Kiszyniowie9. Urodzony w 1919 roku w Warszawie ${ }^{10}$ został wychowany na spolonizowanego Żyda. Sam Wajnberg, choć w swojej twórczości obficie czerpie z tradycji żydowskiej, zawsze bardziej czuł się Polakiem, co podkreślał do końca swojego życia - nie znał hebrajskiego, nie mówił w jidysz ${ }^{11}$. W roku 1939 udało

7 K. Zajas, Widnokresy literatury, w: Na pograniczach literatury, red. J. Fazan, K. Zajas, Biblioteka Literatury Pogranicza, t. 21, seria pod red. A. Romanowskiego, Kraków 2012, s. 5-10.

8 Tamże.

9 W zakresie życiorysu odnoszę się do dwóch monografii poświęconych twórcy: Mieczysław Weinberg: In Search of Freedom, Wolke Verlag, Hofheim 2010 Davida Fanninga oraz wspomnianej już publikacji Danuty Gwizdalanki. Mieczysław Weinberg: In Search of Freedom to pierwsze całościowe ujęcie biografii i twórczości kompozytora, które stanowi punkt wyjścia dla innych opracowań, w tym polskiego: Mieczysław Wajnberg: kompozytor z trzech światów. Wszystkie dane biograficzne pochodzą z dwóch wymienionych pozycji, o ile nie zaznaczono inaczej.

10 Data ta, choć pojawia się w oficjalnych źródłach biograficznych, została zweryfikowana przez Danutę Gwizdalankę. Okazuje się, iż przypadające w 2019 roku stulecie urodzin kompozytora powinniśmy raczej obchodzić rok wcześniej, najprawdopodobniej urodził się bowiem w 1918 roku; zob. D. Gwizdalanka, Nieznane fakty z biografii Mieczysława Wajnberga, https://culture.pl/pl/artykul/ nieznane-fakty-z-biografii-mieczyslawa-wajnberga [dostęp 03.08.2019].

11 Świadectwo Wiktorii Bishop, córki kompozytora, obecnie mieszkającej w Toronto. Kontakt za pomocą technologii internetowej miała miejsce podczas Międzynarodowej Konferencji Weinberg: Between East and West, organizowanej przez Davida Fanninga oraz Michelle Assay w Martin Harris Center for Music 
mu się zbiec z okupowanej Warszawy do Mińska, gdzie studiował w tamtejszym konserwatorium w klasie Wasilija Zołotariowa - wpływy artystyczne romantycznych szkół narodowych były w tym ośrodku wciąż żywe, co wpłynęło na twórczość Wajnberga m.in. w zakresie nawiązywania do melodii ludowych i orkiestracji utrzymanej w późnoromantycznym duchu (jeden z przykładów stanowi Rapsodia na tematy mołdawskie op. 47, napisana długo po opuszczeniu Białorusi). Wajnberg został jednak zmuszony przez los do kolejnej ucieczki, związanej z napaścią hitlerowskich Niemiec na swojego niedawnego sprzymierzeńca w roku 1942. Kompozytor dotarł do Taszkientu, skąd dzięki protekcji Dymitra Szostakowicza udało mu się przenieść do Moskwy w roku 1943, gdzie mieszkał aż do swojej śmierci (1996). Nie sposób nie zauważyć, iż Europa XX wieku, w wyniku naruszenia granic terytorialnych, stała się poprzez masowe (przymusowe bądź ratujące życie) emigracje kontynentem przenikających się ze sobą wpływów, czego Związek Socjalistycznych Republik Radzieckich wydaje się być najbardziej wyrazistym przykładem. Wynikiem swoistej tułaczki Wajnberga stał się język muzyczny (choć na przestrzeni lat ulegający pewnym transformacjom), zawierający w sobie elementy zarówno tradycji rodzimej (mołdawskiej, żydowskiej i polskiej), korzystający z dorobku romantycznych szkół narodowych, uwzględniający tematykę zgodną z wymaganiami partyjnymi, jak i wykazujący wiele paralel stylistycznych w stosunku do twórczości Dymitra Szostakowicza. Prawdopodobnie, mimo odwilży i zmniejszenia restrykcji wobec obywateli żydowskiego pochodzenia po śmierci Józefa Stalina, Wajnberg nigdy nie opuścił Moskwy właśnie ze względu na przyjaźń z Szostakowiczem ${ }^{12}$. Fakt ten wiąże się z kolejną propozycją w typologii Zajasa, pograniczami psychologicznym i egzystencjalnym - związane są one z trudnością tożsamościowej klasyfikacji, właściwej przynależności. Jak pisze Zajas, to „zachwianie poczucia tożsamości przez obecność Innego, zadomowionego w tej samej przestrzeni; jako sposób bycia, egzystencja nomady, poszukującego rozmowy z Innymi" ${ }^{13}$, które w przypadku Wajnberga najpełniej można opisać wraz z trzecim proponowanym

and Drama, University of Manchester, w której uczestniczyłam w dniach 24-27 stycznia 2019 roku. Spotkanie z Wiktorią Bishop zatytułowano Letters from my Father. Obecnie trwają prace nad przygotowaniem monografii pokonferencyjnej, która zostanie wydana nakładem The British Academy.

12 Świadectwo Wiktorii Bishop, Konferencja Mieczysław Weinberg..., Manchester 2019.

13 K. Zajas, Widnokresy literatury..., dz. cyt., s. 8. 
przez Zajasa typem, określanym jako pogranicze socjologiczne. Wiąże się ono z problemem identyfikacji grupowej na płaszczyźnie języka, tożsamości narodowej oraz narodowej mniejszości, powstałym na skutek zakreślania granic swojej egzystencji przez sąsiednie grupy na tym samym terytorium.

Jak już wspomniano, źle rozumiana „potrzeba” identyfikacji Wajnberga jako kompozytora żydowskiego i/lub polskiego, i/lub radzieckiego stanowiła bodaj największą trudność w propagowaniu jego twórczości. Od lat sześćdziesiątych - jak pisze David Fanning „złotych lat" w działalności artystycznej kompozytora - muzyka Wajnberga nie cieszyła się szczególnym zainteresowaniem wydawców i publiczności (jak wspomina słowa ojca Wiktoria Bishop: „w życiu miał on więcej szczęścia do jakości, niż ilości wykonawców”) ${ }^{14}$. W ZSRR Wajnberg uważany był za kompozytora żydowskiego, z kolei w Polsce - za kompozytora radzieckiego, co zamykało jego twórczości drogę na estrady koncertowe. Polskie Ministerstwo Kultury zainteresowało się osobą Wajnberga dopiero w 1994 roku, a pierwsze nagrania CD z utworami kompozytora zostały wydane już po jego śmierci dzięki wielkiemu zaangażowaniu wielbiciela talentu Wajnberga, Tommy'ego Perssona ${ }^{15}$. W związku z żydowskim pochodzeniem, Wajnberga i jego najbliższych wielokrotnie spotykały nie tylko nieprzyjemności, ale i realne zagrożenie życia. Pierwsze zdarzały się nawet w kręgu zaprzyjaźnionych kompozytorów. Podobno Georgij Swiridow, również blisko zaprzyjaźniony z Szostakowiczem, oficjalnie wyrażał pogląd, iż Wajnberg - choć pisze podobnie jak Szostakowicz - nigdy nie zdoła mu dorównać ze względu na swoje żydowskie korzenie ${ }^{16}$. Wajnberg, poprzez małżeństwo ze

14 Świadectwo Wiktorii Bishop. Dzieła Wajnberga wykonywali artyści tej miary co Mścisław Rostropowicz, Światosław Richter czy Dawid Ojstrach.

15 Tommy Persson, Weinberg's last years, wystąpienie podczas międzynarodowej konferencji Mieczysław Weinberg..., Manchester 2019. Materiały niepublikowane.

16 Niepublikowana wypowiedź Daniela Elphicka podczas Międzynarodowej Konferencji Mieczysław Weinberg..., Manchester 2019. Daniel Elphick jest równocześnie autorem znakomitej pracy doktorskiej poświęconej kwartetom Wajnberga. Wspomniana wypowiedź potwierdza założenie Grzegorza Babińskiego, iż nawet w zakresie „pogranicza” istnieją wewnętrzne podziały i ono samo jest uhierarchizowane (G. Babiński, Przemiany pograniczy..., dz. cyt., s. 15). W swojej książce Music behind the Iron Curtain: Mieczysław Weinberg and his Polish contemporaries Elphick dodaje, iż Wajnberg dedykował Swiridowowi swoją Symfonię nr 6 i pomimo antysemickich poglądów Swiridowa pozostawali ze sobą w bliskim kontakcie. Opublikowane po śmierci Swiridowa pamiętniki przedstawiają go jako zagorzałego 
swoją pierwszą żoną, poznaną w Taszkiencie Natalią, został zięciem Solomona Wowsi-Michoelsa. Michoels był nie tylko cenionym aktorem i reżyserem w teatrach żydowskich, ale równocześnie zaangażowanym działaczem i prezesem Żydowskiego Komitetu Antyfaszystowskiego. Koniec lat czterdziestych i początek lat pięćdziesiątych to czas zaostrzenia antysemickiej polityki ZSRR, co poskutkowało wieloma aresztowaniami oraz zabójstwami politycznymi: w wyniku antysemickiej nagonki Solomon Wowsi-Michoels został zamordowany przez NKWD w upozorowanym wypadku samochodowym w 1948 roku, a cała jego rodzina została poddana szczególnej obserwacji władz ${ }^{17}$. Wajnberg został oskarżony o „burżuazyjny formalizm” i osadzony w więzieniu na Łubiance w roku 1953. Kompozytora uwolniono po śmierci Józefa Stalina. Dodatkowo Szostakowicz napisał list do Ławrientija Berii z prośbą o ułaskawienie Wajnberga.

Najpełniejszy „kontakt” z „Innym” w pozytywnym odcieniu znaczeniowym tego słowa kompozytor z pewnością nawiązał z Dymitrem Szostakowiczem, który stał się nie tylko jego wiernym przyjacielem, ale i artystycznym autorytetem. Wajnberg nigdy nie ukrywał, iż muzyka Szostakowicza wywarła na niego decydujący wpływ. Głęboka relacja w życiu prywatnym znalazła swoje naturalne odzwierciedlenie w języku muzycznym Wajnberga, co często stanowi jeden z głównych zarzutów wobec jego twórczości i uznanie go za „epigona” Szostakowicza. Niezwykle krytyczny wobec Wajnberga jest w tej kwestii Aleksander Iwaszkin:

\footnotetext{
Wpływ muzyki Szostakowicza na kompozytorów rosyjskich obejmował wiele płaszczyzn. W latach 6o. wielu twórców przejęło jego styl, w dużej mierze obniżając jego wartość. Wśród jego imitatorów znaleźli się Mosiej Wajnberg, Jurij Lewitin, German Galinin oraz najbardziej utalentowany z nich, Boris Tiszenko. Szostakowicz jednak cenił ich dzieła, gdyż słyszał w nich wiele elementów charakterystycznych dla swojego języka muzycznego. Prawdopodobnie - jak wielu kompozytorów - uległ iluzji, iż w tym właśnie kierunku
}

antysemitę - na tej podstawie można uznać, iż jego poglądy nie stanowiły zatem przeszkody w nawiązaniu przyjaźni z Wajnbergiem, co wydaje się dosyć kontrowersyjne (D. Elphick, Music behind the Iron Curtain. Mieczysław Weinberg and his Polish contemporaries, Cambride University Press, Cambridge 2019, s. 180).

17 W razie śmierci Wajnbergów Szostakowiczowie gotowi byli przyjąć do siebie ich córkę, Wiktorię. 
będzie podążała muzyka przyszłości. Dziś jednak wiadomo, iż utwory te niszczyły muzykę Szostakowicza, zakrywając ją mnóstwem złych kopii ${ }^{18}$.

W rzeczywistości wpływy i inspiracje pomiędzy kompozytorami przebiegały równolegle - prawdopodobnie wątki żydowskie pojawiły się w twórczości Szostakowicza właśnie dzięki przyjaźni z polskim twórcą.

Nomadyczna biografia Wajnberga zaowocowała swoistą muzyczną „trójjęzycznością", będącą połączeniem elementów ojczystych, szkoły Zołotariowa oraz stylistyki bliskiej muzyce Dymitra Szostakowicza. Każdy z tych języków miał pomóc mu w nawiązaniu komunikacji $\mathrm{z}$ „Innym” w nowo zastanej rzeczywistości, a pierwszy z nich - podkreśleniu swoich korzeni. Elementy rodzime reprezentują m.in. idiomy muzyki żydowskiej, nieraz jarmarcznej, naśladującej klezmerską kapelę (Wajnberg nawiązuje w ten sposób do swego dzieciństwa: jego ojciec tworzył muzykę rewiową i teatralną). Istotną rolę stanowią nawiązania do muzyki Fryderyka Chopina, zwłaszcza w postaci cytatów w Symfonii $n r 8$ „Kwiaty polskie” op. 83 oraz Symfonii $n r 21$ „Kadisz" op. ${ }^{152^{19}}$. Chopin nie tylko należał do ulubionych kompozytorów Wajnberga - Wajnberg odczuwał z polskim romantykiem wspólnotę doświadczeń w zakresie przeżywania emigracyjnego losu. Dodatkowo muzyka Chopina przywoływała wspomnienia z czasów nauki w Konserwatorium Warszawskim. Wajnberg uchodził za jednego z najzdolniejszych uczniów Józefa Turczyńskiego, profesora Witolda

18 A. Ivashkin, Shostakovich and Schnittke: the erosion of symphonic syntax, w: Shostakovich. Studies, red. D. Fanning, Cambridge University Press, Cambridge 1995, s. 254-255). Sam Szostakowicz cenił muzykę Wajnberga: „Muzykę Wajnberga zawsze cenił i lubił. Kiedyś poświęcił temu kompozytorowi swój $X$ Kwartet. Napisał również szkic do programu opery Wajnberga Madonna i żołnierz w 1975 roku. Z kolei „Z radością opowiadał o nowej operze Mojsieja Wajnberga Pasażerka. »To zadziwiające dzieło... - powtarzał wielokrotnie - ...nadzwyczajna opera «" (K. Meyer, Dymitr Szostakowicz i jego czasy, PWN, Warszawa 1999, s. 327, 340). Z kolei Wajnberg nie widział niebezpieczeństwa w naśladowaniu stylu muzycznego Szostakowicza, o czym świadczyć miały jego słowa w obronie X Symfonii przyjaciela: „Przeciwstawiał się tezie, że muzyka Szostakowicza istnieje sama dla siebie. Dodał, iż jego zdaniem w samym tylko Kraju Rad mieszkają dziesiątki tysięcy wielbicieli tego kompozytora. Wyznał również, że nie widzi nic złego w tym, iż młode pokolenie kompozytorskie znajduje się w zasięgu wpływów muzyki autora X Symfonii" (K. Meyer, Dymitr Szostakowicz..., dz. cyt., s. 240-241).

19 Kompozytor w Kwiatach polskich wykorzystał cytat z Chopinowskiej Sonaty b-moll op. 35 (część trzecia - Marche funèbre: Lento), natomiast w Kadiszu - z Ballady g-moll op. 23. 
Małcużyńskiego, zdobywcy trzeciej nagrody podczas trzeciej edycji Międzynarodowego Konkursu Pianistycznego im. Fryderyka Chopina. W Wajnbergu upatrywano laureata kolejnej edycji tego wydarzenia, a usłyszany przez Józefa Hoffmana otrzymał propozycję podjęcia nauki w Filadelfii. Wyjazd jednak nie doszedł do skutku: Wajnberg nie otrzymał wizy z powodu żydowskiego pochodzenia. „Zakorzenieniu” służył kompozytorowi również głęboki autobiografizm jego twórczości. $\mathrm{Za}$ artystyczne credo przyjął danie świadectwa o tragicznej historii swojego narodu, występując tym samym w imieniu wszystkich ofiar europejskich ustrojów totalitarnych. Wierząc w głęboką ideę humanizmu, podążał w swej sztuce za potrzebą podtrzymywania pamięci o horrorze II wojny światowej, by podobne okrucieństwo już nigdy nie miało miejsca. Jak powiedział sam kompozytor:

\footnotetext{
Wiele moich utworów związanych jest $\mathrm{z}$ wojną. Ale to nie ja wybierałem ten temat. Podyktował mi go los, tragiczny los moich bliskich. Uważam za swój obowiązek moralny pisanie o wojnie, o strasznym losie, jaki zgotował ludziom nasz wiek ${ }^{20}$.
}

Jeśli uważam siebie za osobę wyróżnioną poprzez ocalenie życia, fakt ten daje mi swoiste przekonanie, że spłacenie długu jest niemożliwe, że nawet ciężka praca twórcza dwadzieścia cztery godziny na dobę, przez cztery dni w tygodniu nie przybliży mnie ani o cal do tej spłaty ${ }^{21}$.

Kolejny typ, pogranicze mitograficzne, dotyczy przestrzeni o „szczególnym znaczeniu kulturowym, jak to się dzieje np. w przypadku pojęcia Kresów”22. Przyjmuję, iż „pogranicze mitograficzne” dotyczy również przestrzeni o szczególnym dla autora tekstu znaczeniu, któremu nadaje on sens symboliczny, niemal legendarny. Miejscem takim dla Wajnberga zdaje się być Warszawa, aż do przełomowego momentu w roku 1966. Nie ulega wątpliwości, iż Warszawa czasu dzieciństwa i młodości utrwaliła się w wyobraźni kompozytora jako czas beztro-

20 D. Gwizdalanka, Mieczysław Wajnberg..., dz. cyt., s. 60.

21 H. Milewska, Mieczysław Weinberg - muzyczne dziękczynienie, „HFiM” 2/2011, https://hi-fi.com.pl/sylwetki-muzyczne-lista/740-mieczys\%C5\%82aw-weinbergmuzyczne-dzi\%C4\%9gkczynienie.html [dostęp 03.08.2019].

22 K. Zajas, Widnokresy literatury..., dz. cyt., s. 8. 
ski, rodzinnego szczęścia i bezpieczeństwa, pierwszych artystycznych sukcesów. W roku 1966 po raz pierwszy i jedyny od swojego wyjazdu miał okazję odwiedzić Polskę jako delegat ZSRR na Międzynarodowym Festiwalu Muzyki Współczesnej Warszawska Jesień. Wiadomo, iż spotkanie $\mathrm{z}$,rajem utraconym” było dla Wajnberga wielkim rozczarowaniem; jak wspomina druga córka kompozytora, Anna:

Podróż taty do Polski była dla niego bardzo przykra. Nie spotkał prawie nikogo z czasów swojej młodości [...] Był smutny, ponieważ Warszawa została całkowicie zrekonstruowana, a wielu przyjaciół odeszło ${ }^{23}$.

\section{Szerzej sytuację komentuje Krzysztof Meyer:}

Znałem jego nazwisko [Wajnberga - ANZ], gdyż regularnie czytując „Sowietską Muzykę" coraz to napotykałem informacje o jego utworach, a ponadto $\mathrm{w}$ domu miałem kilka radzieckich płyt z nagraniami jego muzyki. Bardzo mi się podobała, na przykład druga Sinfonietta. Tak więc zainteresowałem się Wajnbergiem i od razu mieliśmy o czym rozmawiać. Inni polscy kompozytorzy unikali go. Wynikało to $\mathrm{z}$ negatywnego nastawienia do polityki kulturalnej prowadzonej przez Rosjan, gdyż utwory delegowanych do nas kompozytorów prawie bez wyjątku były konwencjonalne, tradycyjne, a my od festiwalu oczekiwaliśmy czegoś innego niż dobre rzemiosło - woleliśmy Edisona Denisowa albo Alfreda Sznitkego. Wajnberg także nie pasował do warszawsko-jesiennego pejzażu. Jedynym Polakiem, który szukał z nim kontaktu był Zbigniew Turski, ponieważ przed wojną razem studiowali i to Wajnberg zagrał wtedy jego koncert fortepianowy. Takie przyjęcie musiało być dla Wajnberga gorzkim doświadczeniem. W końcu Polska była jego utraconą ojczyzną, a polski - językiem ojczystym. Wysławiał się w nim nadal bezbłędnie, bez jakichkolwiek naleciałości z mowy potocznej, słowa artykułując tak, jakby je wydrukowano. Mówił przedwojenną, inteligencką polszczyzną - wypielęgnowaną i ładnie brzmiącą. Tego, że większość kolegów zachowywała wobec niego dystans, nie przeżywał chyba jednak zbyt dramatycznie... Największym rozczarowaniem było to, że miasto, które pamiętał z przeszłości, przestało istnieć ${ }^{24}$.

23 D. Elphick, Music behind the Iron Curtain..., dz. cyt., s. 193.

24 K. Meyer, Im Schatten Schostakowitchs, „Opernwelt” 2010/6, s. 42-43, cyt. za: D. Gwizdalanka, Mieczysław Wajnberg..., dz. cyt., s. 40. 
Kategoria pogranicza we wszelkich przejawach rozumienia tego terminu wskazuje jednoznacznie, iż próba „przyporządkowania” twórcy jednej z tożsamości skazana jest na niepowodzenie. Intuicję tę potwierdza refleksja Daniela Elphicka, który apeluje o ponowne „rozpatrzenie" muzycznej spuścizny Wajnberga, pozbawione kulturowego wartościowania. Za jedyną słuszną drogę uważa przyjęcie jej jako

utkanej z żydowskich, sowiecko-rosyjskich oraz polskich wpływów i doświadczeń. W ten sposób zrozumiemy ją jako ekspresję kompletnej i wszechstronnej istoty ludzkiej, a nie jedynie jako prostą kulminację którejkolwiek $\mathrm{z}$ tradycji narodowych ${ }^{25}$.

W tej perspektywie dorobek muzyczny Mieczysława Wajnberga jako „twórcy z pogranicza” nabiera cech wybitnie indywidualnych, stając się zarazem niezwykle wartościowym świadectwem czasów, w jakich przyszło mu żyć - unikalnym w historii światowej literatury muzycznej.

25 D. Elphick, Music behind the Iron Curtain..., dz. cyt., s. 262-263. 


\section{Bibliografia}

\section{Opracowania}

Babiński G., Przemiany pograniczy narodowych i kulturowych - propozycje typologii, w: Polskie pogranicza a polityka zagraniczna u progu XXI wieku, red. R. Stemplowski, A. Żelazo, Warszawa 2002.

Elphick D., Music behind the Iron Curtain. Mieczysław Weinberg and his Polish contemporaries, Cambridge University Press, Cambridge 2019. Fanning D., Mieczysław Weinberg: In Search of Freedom, Wolke Verlag, Hofheim 2010.

Gwizdalanka D., Mieczysław Wajnberg: kompozytor z trzech światów, Teatr Wielki im. Stanisława Moniuszki w Poznaniu, Poznań 2013. Gwizdalanka D. Nieznane fakty $z$ biografii Mieczysława Wajnberga, https://culture.pl/pl/artykul/nieznane-fakty-z-biografiimieczyslawa-wajnberga [dostęp 03.08.2019].

Ivashkin A., Shostakovich and Schnittke: the erosion of symphonic syntax, w: Shostakovich. Studies, red. D. Fanning, Cambridge University Press, Cambridge 1995.

Meyer K., Dymitr Szostakowicz i jego czasy, PWN, Warszawa 1999.

Milewska H., Mieczysław Weinberg - muzyczne dziękczynienie, „HfiM” 2/2011, https://hi-fi.com.pl/sylwetki-muzyczne-lista/740mieczys\%C5\% 82aw-weinberg-muzyczne-dzi\%C4\%9gkczynienie. html [dostęp 03.08.2019].

Panas W., O pograniczu etnicznym $w$ badaniach literackich, w: Wiedza o kulturze i edukacja. Księga referatów Zjazdu Polonistów, red. T. Michałowska, Z. Goliński, Z. Jarosiński, Instytut Badań Literackich PAN, Warszawa 1996.

Próchnicki W., Pogranicza bez granic, w: Na pograniczach literatury, red. J. Fazan, K. Zajas, Biblioteka Literatury Pogranicza, t. 21, seria pod red. A. Romanowskiego, Kraków 2012.

Zajas K., Widnokresy literatury, w: Na pograniczach literatury, red. J. Fazan, K. Zajas, Biblioteka Literatury Pogranicza, t. 21, seria pod red. A. Romanowskiego, Kraków 2012. 
Inne źródła

Bishop V., Letters from my Father, spotkanie z córką kompozytora w ramach Międzynarodowej Konferencji Mieczysław Weinberg: Between East and West, organizowanej przez D. Fanninga oraz M. Assay, Martin Harris Centre for Music and Drama, University of Manchester, Manchester 2019 [materiał niepublikowany].

Persson T., Weinberg's last years, wystąpienie podczas Międzynarodowej Konferencji Mieczystaw Weinberg: Between East and West, organizowanej przez D. Fanninga oraz M. Assay, Martin Harris Centre for Music and Drama, University of Manchester, Manchester 2019 [materiał niepublikowany]. 